\title{
Response to the Article by Adanipar et al.: The First Report of a Patient with Probable Variant Creutzfeldt-Jakob Disease in Turkey, Dement Geriatr Cogn Disord Extra 2011;1:429-432
}

\section{Dear Editor}

It is essential that all cases of variant Creutzfeldt-Jakob disease (vCJD) are reported as the incidence and geographic distribution of cases inform public health policy. Validated criteria for the classification of cases of suspected vCJD [1] have been agreed on internationally and contain obligatory preconditions, the presence of specific clinical features, and the results of specialist investigations, including the 'pulvinar sign' on MRI brain scan. A definitive diagnosis of VCJD requires neuropathological confirmation, either at brain biopsy or autopsy.

The case described by Adanipar et al. [2] has been reported as a case of 'probable variant Creutzfeldt-Jakob disease'. However, although the clinical features would be compatible with this condition, other characteristics of the case make this diagnosis unlikely. One of the preconditions for the diagnosis of $\mathrm{VCJD}$ is that there should be 'no evidence of a familial form of TSE', but the authors have identified a P102L mutation, an abnormality associated with the familial prion disease Gerstmann-Straussler disease [3]. The codon 129 genotype was heterozygous, which has not been identified, to date, in any definite or probable case of vCJD. The MRI scan images published in the article show high signal in the caudate and lentiform nuclei, appearances seen in sporadic CJD [4], and not the 'pulvinar sign' which is characteristic of vCJD.

The case reported is of significant interest, but the suggested diagnosis of vCJD cannot be regarded as correct unless there is neuropathological verification of this diagnosis.

Yours sincerely,

The EUROCJD Group 


\section{References}

-1 Heath CA, Cooper SA, Murray K, Lowman A, Henry C, Macleod MA, Stewart GE, Zeidler M, Mackenzie JM, Ironside JW, Summers DM, Knight RS, Will RG: Validation of diagnostic criteria for variant Creutzfeldt-Jakob disease. Ann Neurol 2010;67:761-770.

-2 Adapınar DÖ, Saylısoy S, Yenilmez Ç, Aslan H, Ertan B, Artan S, Güleç G, Susuz Ç, Adapınar B: The first report of a patient with probable variant Creutzfeldt-Jakob disease in Turkey. Dement Geriatr Cogn Disord Extra 2011;1:429-432.

-3 Kovacs GG, Trabattoni G, Hainfellner JA, Ironside JW, Knight RSG, Budka H: Mutations of the prion protein gene: phenotypic spectrum. J Neurol 2002;249:1567-1582.

-4 Zerr I, Kallenberg K, Summers DM, Romero C, Taratuto A, Heinemenn U, Breithaupt M, Varges D, Meissner B, Ladogana A, Schuur M, Haik S, Collins SJ, Jansen GH, Stokin GB, Pimentel J, Hewer E, Collie D, Smith P, Roberts H, Brandel JP, van Duijn C, Pocchiari M, Begue C, Cras P, Will RG, Sanchez-Juan P: Updated clinical diagnostic criteria for sporadic Creutzfeldt-Jakob disease. Brain 2009; 132:2659-2668. 